\title{
Prevalence of current patterns and predictive trends of multidrug-resistant Salmonella Typhi in Sudan
}

\author{
Ayman A. Elshayeb ${ }^{1 *}$, Abdelazim A. Ahmed ${ }^{1,2}$, Marmar A. El Siddig ${ }^{1}$ and Adil A. El Hussien ${ }^{1}$
}

\begin{abstract}
Background: Enteric fever has persistence of great impact in Sudanese public health especially during rainy season when the causative agent Salmonella enterica serovar Typhi possesses pan endemic patterns in most regions of Sudan - Khartoum.

Objectives: The present study aims to assess the recent state of antibiotics susceptibility of Salmonella Typhi with special concern to multidrug resistance strains and predict the emergence of new resistant patterns and outbreaks.

Methods: Salmonella Typhi strains were isolated and identified according to the guidelines of the International Standardization Organization and the World Health Organization. The antibiotics susceptibilities were tested using the recommendations of the Clinical Laboratories Standards Institute. Predictions of emerging resistant bacteria patterns and outbreaks in Sudan were done using logistic regression, forecasting linear equations and in silico simulations models.

Results: A total of 124 antibiotics resistant Salmonella Typhi strains categorized in 12 average groups were isolated, different patterns of resistance statistically calculated by $(y=a x-b)$. Minimum bactericidal concentration's predication of resistance was given the exponential trend $\left(y=n e^{x}\right)$ and the predictive coefficient $R^{2}>0<1$ are approximately alike. It was assumed that resistant bacteria occurred with a constant rate of antibiotic doses during the whole experimental period. Thus, the number of sensitive bacteria decreases at the same rate as resistant occur following term to the modified predictive model which solved computationally.

Conclusion: This study assesses the prediction of multi-drug resistance among $\mathrm{S}$. Typhi isolates by applying low cost materials and simple statistical methods suitable for the most frequently used antibiotics as typhoid empirical therapy. Therefore, bacterial surveillance systems should be implemented to present data on the aetiology and current antimicrobial drug resistance patterns of community-acquired agents causing outbreaks.
\end{abstract}

Keywords: Antibiotics, Ciprofloxacin, Salmonella Typhi, Prediction, Resistance

\section{Background}

Globally the burden of typhoid fever victims are 20 million as a main issue of morbidity and mortality in developing countries $[1,2]$. In Sudan, approximate numbers of typhoid infection is increasing during rainy season in association with malaria incidents [3-5]. Salmonella Typhi as causative organism has rapidly gained resistance to antibiotics like ampicillin, chloramphenicol and

\footnotetext{
*Correspondence: ayman_elshayeb@yahoo.com

1 Faculty of Science, University of Khartoum, Khartoum, Sudan

Full list of author information is available at the end of the article
}

cotrimoxazole, and also to previously effective drugs namely fluoroquinolone [6]. Resistance to the antimicrobial agents such as trimethoprim-sulfamethoxazole, chloramphenicol and amoxicillin has been increasingly reported among $S$. Typhi isolates. In addition, quinolone resistance has been reported from Southeast Asia and the Indian subcontinent. Determining the patterns of antimicrobial resistance is essential in recommending effective treatment for bacterial infection $[7,8]$. The incidence of multidrug resistant $S$. Typhi was found to be increasing globally and has been a scourge for those afflicted with enteric fever all over the world, while there are many 
reports noting decline in susceptibility to ciprofloxacin [9]. Resurgence of resistant Salmonella well-known as increasing to the amount of multi drug resistant strains against nalidixic acid even though the isolates were sensitive to ceftriaxone and ciprofloxacin [10]. Until now, Ciprofloxacin is a promising antibiotic against numerous bacterial infections, for its ability to penetrate into the macrophages and to kill multidrug-resistant strains [11]. On the other hand, emergence of resistant Salmonella strains against fluoroquinolone has been reported [12-14]. Since fluoroquinolone has broad spectrum, potency, and oral efficacy, it could be useful for oral treatment of general bacterial infections [15]. Therefore, it is necessary for susceptibility pattern of the particular strain isolated from patient to be determined by the sensitivity test in vitro [16]. Variation in patterns of susceptibility of $S$. Typhi is important to monitor it and provide suitable guidelines on fluoroquinolone treatment given as oral tablets that have better absorption from the gastrointestinal tract after oral administration [17]. Routine investigation for the antibiotics members of fluoroquinolone MICs in patients presenting with invasive Salmonella infections should be done [18]. However, revealing increased resistance to ciprofloxacin (MICs, $0.125-1 \mu \mathrm{g} /$ $\mathrm{mL} / \mathrm{L}$ ) had emerged and become endemic in South and South-East Asia, also such strains have also been described from other parts of the globe $[19,20]$. Accordingly, there is treatment collapse of fluoroquinolones in patients infected with these organisms, because isolates with reduced susceptibility to fluoroquinolones might become highly resistant to sequential increasing of mutations in topoisomerase genes [21, 22]. The prediction of drug efficiency started by the use of uncomplicated screening tools such as implying antibiotic discs are of great value [23]. For predicting resistance and outbreaks problems, it is essential to create the mathematical timeseries incorporate any sort of statistical trend, otherwise by definition forecasting would be impossible [24]. The application of in silico models' parameters that assessed the estimated efficiency of any antibiotic therapy in specific bacterial population dynamics, required the computational simulation and mathematical data analysis. It also required the possibility to monitor the outbreaks occurrence on the suspected environment and to mark the actual MIC spread values [25].

\section{Objectives}

This work was conducted to evaluate the recent efficiency of common antibiotics used against Salmonella Typhi in Sudan and predict the future trends and fluctuations of susceptibility using inexpensive materials and simple statistical methods to support the decision for antimicrobial choice and dosage especially during rainy season and outbreaks.

\section{Methods \\ Isolation of Salmonella Typhi}

Environmental samples collected from wastewaters of Omdurman Military Hospital and Soba Stabilization Station ponds, showed positive numbers of Multidrug Salmonella Typhi $(\mathrm{n}=128)$. Laboratory investigations were done immediately after collections include; cultural characteristics and biochemical tests were performed according to the recommendations of [26] standards. Serotyping was done using polyvalent $\mathrm{O}$-anti sera $\mathrm{A}-\mathrm{G}$ and $\mathrm{H}$ (flagellar)-anti sera formula.

\section{Antibiotic susceptibility}

The antimicrobial susceptibilities of the isolated strains were tested following the Clinical Laboratory Standards Institute guidelines [27]. The experimented antibiotics were those commonly used for Gram negative bacteria by Kirby Bauer disk diffusion susceptibility test which include; tetracycline $\left(\mathrm{TE}_{30 \mathrm{mcg}}\right)$, ofloucin $\left(\mathrm{OF}_{5 \mathrm{mcg}}\right)$, cefroxin $\left(\mathrm{CXM}_{30 \mathrm{mcg}}\right)$, cotrimoxazole $\left(\mathrm{COT}_{25 \mathrm{mcg}}\right)$, amoxyclar $\left(\mathrm{AMC}_{30 \mathrm{mcg}}\right)$, gentamycin $\left(\mathrm{GEN}_{30 \mathrm{mcg}}\right)$ and ciprofloxacin $\left(\mathrm{Cip}_{5 \mathrm{mcg}}\right)$. The discs were placed on the top surface of the agar plates, inoculated with Salmonella Typhi and incubated overnight at $37^{\circ} \mathrm{C}$. The diameters of inhibition zones were calculated using reference tables to determine whether the bacteria are sensitive (S), intermediate (I) or resistant $(\mathrm{R})$ to the certain antibiotic. A standard E. coli strain ATCC 25922 was also tested for quality control [28].

Determination of minimum inhibition concentration (MIC) Bacterial suspensions were made in sterile nutrient broth by colonies from a pure cultures and the turbidity adjusted to $0.5 \mathrm{McFarland}$ standards to make a concentration of about $10^{7} \mathrm{CFU} / \mathrm{mL}$. Sensitivity to ciprofloxacin was evaluated by the macro-dilution test according the criteria stipulated by the [29] with serial Ciprofloxacin dilutions of $8,16,32,64$ and $128 \mu \mathrm{g} / \mathrm{mL}$ respectively. Results were recorded as minimum inhibitory concentrations (MIC). A standard E. coli strain ATCC 25922 was also tested for quality control.

\section{Determination of minimum bactericidal concentration (MBC)}

Following the MICs determination, $100 \mu \mathrm{L}$ were aspirated from the wells of the micro-plates that showed growth inhibition and then inoculated on the top surface of plates containing Mueller-Hinton agar medium. Plates were incubated overnight and examined visually for 
Table 1 Probabilities of multi drug resistance occurrence

\begin{tabular}{|c|c|c|}
\hline Interpretation & $\begin{array}{l}\text { Ciprofloxacin concen- } \\
\text { tration } \mu \mathrm{g} / \mathrm{mL}\end{array}$ & $\begin{array}{l}\text { Probability of resistance } \\
\text { occurrence } \%\end{array}$ \\
\hline Control & 0.0 & 0 \\
\hline$S \geq$ & 8.0 & 25 \\
\hline$I=$ & 16.0 & 42 \\
\hline$R \leq$ & 32.0 & 58 \\
\hline$R \leq$ & 64.0 & 75 \\
\hline$R \leq$ & 128.0 & 92 \\
\hline
\end{tabular}

bacterial growth. A standard strain E. coli ATCC 25922 was also tested for quality control.

\section{Probability of antibiotics resistance (\%)}

To determine the thresholds of bacteria resistance to ciprofloxacin, statistical probabilities for MBCs breakpoints were done by trending normal probability plot.

\section{Prediction of antibiotics resistance}

Time-series prediction (calculated from the current susceptibility pattern) was employed by using simple statistical systems (regression and simple moving average) for the temporal variations in Salmonella Typhi sensitivity or resistance towards antibiotics and resulted in (Tables 2 and 3). In silico model of outbreak was created for solving the prediction of bacteria resistance due to periodic samples collections [30].

\section{Results}

Isolation and identification of S. typhi

From the recovered bacteria species, 128 were identified as Salmonella Typhi, the isolates stereotyping showed that; 9 groups $(75 \%)$ had the antigenic formula O:9( $\left.D_{1}\right)$ for Salmonella Typhi, 3 groups (25\%) had the formula Salmonella enteric Paratyphi A 1,2,12 a [1,5] and Salmonella enterica Paratyphi C1 6,7,[Vi] c 1,5 respectively.

\section{Antibiotics susceptibility test}

Different patterns of susceptibility were shown by the $12 \mathrm{~S}$. typhi isolated groups for their response against the seven tested antibiotics. Salmonella Typhi defined as multi drug resistant when isolate resist two or more tested antibiotics, exceptions were $\mathrm{COT}_{25 \mathrm{mcg}}, \mathrm{GEN}_{30 \mathrm{mcg}}$ and $\mathrm{Cip}_{5 \mathrm{mcg}}$ which were susceptible. However, three isolates (S3, S4 and S6) had intermediate resistance to $\mathrm{GEN}_{30 \mathrm{mcg}}$. Eight isolates were resistant to $\mathrm{CXM}_{30 \mathrm{mcg}}$.

Antibiogram or (in vitro-sensitivity) showed susceptibility patterns of Salmonella Typhi isolated groups that have developed resistance against most antibiotics (multi drug resistant) including cotrimoxazole, gentamycin and ciprofloxacin and interpreted as MIC $\geq 32 \mu \mathrm{g} / \mathrm{mL}$.

Table 2 Prediction of antibiotics resistance interpreted of $16 \mu \mathrm{g} / \mathrm{mL}$

\begin{tabular}{|c|c|c|c|c|c|c|c|c|c|c|c|c|c|}
\hline Incubation & E. coli & Dr 11 & Dr 14 & S1 & S2 & S3 & S4 & S5 & S6 & S7 & S8 & S9 & $\mathrm{S} 10$ \\
\hline Actual $12 \mathrm{~h}$ & 6 & 9 & 6 & 5 & 4 & 3 & 3 & 5 & 6 & 6 & 7 & 9 & 8 \\
\hline Day 1 & 7 & 9 & 5 & 6 & 4 & 3 & 5 & 6 & 6 & 6 & 7 & 9 & 9 \\
\hline Day 2 & 8 & 8 & 7 & 5 & 5 & 4 & 6 & 6 & 7 & 7 & 8 & 10 & 11 \\
\hline Day 3 & 8 & 9 & 7 & 6 & 5 & 4 & 7 & 7 & 7 & 7 & 9 & 12 & 12 \\
\hline Day 4 & 9 & 10 & 8 & 7 & 5 & 5 & 6 & 7 & 7 & 7 & 9 & 12 & 12 \\
\hline Day 5 & 9 & 11 & 8 & 7 & 6 & 5 & 6 & 8 & 8 & 8 & 11 & 13 & 13 \\
\hline Day 6 & 9 & 12 & 8 & 8 & 7 & 6 & 8 & 9 & 8 & 8 & 13 & 14 & 13 \\
\hline Day 7 & 9 & 13 & 8 & 8 & 7 & 6 & 8 & 9 & 9 & 8 & 16 & 15 & 14 \\
\hline
\end{tabular}

Predicting low-level resistance of antibiotics at $16 \mu \mathrm{g} / \mathrm{mL}$ as intermediate dose among $S$. Typhi is an indicator of treatment failure in the nearest future

Table 3 Prediction of antibiotics resistance interpreted of $32 \mu \mathrm{g} / \mathrm{mL}$

\begin{tabular}{|c|c|c|c|c|c|c|c|c|c|c|c|c|c|}
\hline Incubation & E. coli & Dr 11 & Dr 14 & S1 & S2 & S3 & S4 & S5 & S6 & S7 & S8 & S9 & $\mathrm{S} 10$ \\
\hline Actual $12 \mathrm{~h}$ & 1 & 8 & 3 & 1 & 2 & 1 & 1 & 2 & 2 & 2 & 5 & 6 & 4 \\
\hline Day 1 & 1 & 9 & 6 & 2 & 2 & 2 & 1 & 2 & 3 & 2 & 5 & 6 & 5 \\
\hline Day 2 & 1 & 10 & 7 & 4 & 2 & 2 & 1 & 2 & 3 & 3 & 6 & 7 & 5 \\
\hline Day 3 & 2 & 10 & 8 & 6 & 3 & 2 & 1 & 3 & 3 & 3 & 6 & 7 & 6 \\
\hline Day 4 & 2 & 10 & 9 & 7 & 4 & 2 & 2 & 3 & 3 & 3 & 7 & 8 & 7 \\
\hline Day 5 & 3 & 10 & 10 & 8 & 6 & 3 & 2 & 3 & 4 & 3 & 7 & 8 & 7 \\
\hline Day 6 & 4 & 11 & 10 & 9 & 7 & 4 & 3 & 3 & 4 & 3 & 8 & 9 & 7 \\
\hline Day 7 & 5 & 12 & 11 & 10 & 8 & 6 & 3 & 4 & 5 & 4 & 8 & 10 & 8 \\
\hline
\end{tabular}




\section{Minimum inhibitory concentration (MIC)}

The MIC of ciprofloxacin against the $S$. Typhi isolated strain and the control E. coli strain indicated that two $S$. Typhi Dr11 and S8 were capable to tolerate ciprofloxacin as high as $32 \mu \mathrm{g} / \mathrm{mL}$, five (S3, S6, S7, S9 and S10) can grow in $16 \mu \mathrm{g} / \mathrm{mL}$ and four isolates (Dr14, S1, S4 and S5) showed no growth at concentrations higher than $8 \mu \mathrm{g} /$ $\mathrm{mL}$ while isolate $\mathrm{S} 2$ could not tolerate any of the tested ciprofloxacin concentrations. Therefore, any isolated strain that showed resistance to ciprofloxacin higher than $16 \mu \mathrm{g} / \mathrm{mL}$ was considered as resistant isolate. The means of (33.0\%) of the isolates found to be multi-drug resistant strains and categorized in 8 main groups namely (S. Typhi 16, S. Typhi 32, S.7 16, S.7 32, Dr11 16, Dr11 32, Sal C 16, Sal C 32). The Minimum Inhibitory Concentrations MICs were determined at 16 and $32 \mu \mathrm{g} / \mathrm{mL}$ concentrations, and (67.0\%) isolates that resist ciprofloxacin as minimum bactericidal concentration (MBCs).

\section{Minimum bactericidal concentration (MBC)}

The MBC breakpoints of the $12 \mathrm{~S}$. Typhi and the control E. coli can tolerate $32 \mu \mathrm{g} / \mathrm{mL}$ antibiotics indicating an emergence of resistance against this antibiotic that should have more attention.

\section{Probabilities of antibiotics resistance occurrence among (MBCs)}

Statistical analysis between antibiotics' concentrations $\mu \mathrm{g} / \mathrm{mL}$ and MBCs breakpoints was done by MBCs trending plot for the probability of resistance occurrence.

According to the data obtained from the tested patterns of susceptibility, the probability of an isolate to develop resistance increases with antibiotics concentration increasement as shown in (Table 1). The determination of Spearman coefficient ( $\mathrm{R}$-square) was calculated $\mathrm{R}^{2}=0.8568$ and its corresponding $\mathrm{p}$ value was founded $(\mathrm{p}=0.022038522)$. For the estimation of the regression lines, each of the data points was plotted and weighted by the inverse of the variance and the rate of regression $\left(y=3.0919 \mathrm{e}^{0.0162 \mathrm{x}}\right)$.

The plotted graph showed the percentage probability of MBCs to resist antibiotics concentrations and their empirical observations were solved by

$$
(y=n x-b) \text {. }
$$

The Spearman coefficient of determination was calculated $\mathrm{R}^{2}=0.8381$ and it corresponds significantly to the rate of resistance occurrence by $(y=0.0235 x-0.0411)$.

\section{Prediction of antibiotics susceptibility trends}

The prediction of possible resistance occurrence was statistically estimated by regression and simple moving average for certain period of incubation with antibiotics. The increasing numbers of MBCs equal to the probability of more cells grown with antibiotics and develop resistance during the first $12 \mathrm{~h}$ and calculated for the next 7 days of incubation period as shown in (Tables 2 and 3).

Predicting high-level resistance of antibiotics at $32 \mu \mathrm{g} /$ $\mathrm{mL}$ as resisted dose among $S$. Typhi is an indicator of total treatment failure. It is clear that both Tables 2 and 3 showed the numbers of resisted colonies have daily developed increasing resistance with no specific pattern.

Minimum bactericidal concentration's predication of $E$. coli ATCC 25922 resistance was given by $\left(y=6.2391 \mathrm{e}^{0.0513 x}\right)$ and the coefficient $\left(\mathrm{R}^{2}=0.7\right)$. Salmonella Typhi, (Dr11, Dr14, S1...S10) were obtained by the exponential trend

$$
\left(\mathrm{y}=\mathrm{n} \mathrm{e}^{\mathrm{x}}\right)
$$

and the coefficient $\mathrm{R}^{2}>0<1$ are approximately alike.

The bacteria resistance after long term of incubation period with antibiotics was predicted by $\left(\mathrm{y}=\mathrm{n} \mathrm{e}^{\mathrm{x}}\right)$, where (n) is the numbers of colonies (MBCs) and $\left(e^{x}\right)$ is the exponent positive integers which corresponds to increasing probabilities of resistance incident at certain time. The predictive coefficient $R^{2}$ value for each isolate of antibiotics concentrations (16 and $32 \mu \mathrm{g} / \mathrm{mL}$ ) are shown in (Figs. 3 and 4).

The solution of the linear equation $\left(y=n e^{x}\right)$ on plotted Excel sheet solved the prediction of long term incubated bacteria with antibiotics. The predictive patterns of all isolated strain showed increasing in their exponential trends of antibiotics concentrations of 16 and $32 \mu \mathrm{g} / \mathrm{mL}$ which correlate to the increasing probabilities of resistance occurrence (Table 4), the table also showed high values of coefficient $R^{2}>0.5$ and this indicates how well data fit the statistical model.

\section{In silico simulation for predicting patterns of outbreak}

For long term predicting of MDR Salmonella Typhi in certain period (5 years) for outbreak purposes, a monitoring simulated system was created from bacteria collected during study period to predict population dynamics especially during rainy season and/or outbreak (Additional file 1). In ideal microbial community dynamics, the normal bacteria growth rate is given by

$$
\mathrm{N}_{\mathrm{t}}=\mathrm{N}_{0} *(1+\mathrm{r})^{\mathrm{t}},
$$

where $\mathrm{N}_{\mathrm{t}}$ : bacterial amount at time $\mathrm{t}, \mathrm{N}_{0}$ : bacterial amount at time $0, \mathrm{r}$ : growth rate and $\mathrm{t}$ : time passed.

Introducing antibiotic to the population gives different interactions of Salmonella Typhi and become

$[(\mathrm{N})=$ Replicated population + Resistance - Mortality $]$.

Since multidrug resistant Salmonella Typhi (N) affected by antibiotics $(\Delta)$ and denoted by $(\alpha)=$ range 
Table 4 Results of linear predictive patterns of resistance in Salmonella Typhi

\begin{tabular}{lllll}
\hline Sample & \multicolumn{1}{l}{$\mathbf{l} \boldsymbol{\mu \mathbf { g } / \mathbf { m L }}$} & & $\mathbf{3 2} \boldsymbol{\mu \mathbf { g } / \mathbf { m L }}$ \\
\cline { 2 - 3 } & Exponential trend & Coefficient & Exponential trend & Coefficient \\
\hline E. coli ATCC 25922 & $y=6.2391 e^{0.0513 x}$ & $R^{2}=0.7208$ & $y=0.5978 e^{0.2636 x}$ & $R^{2}=0.9455$ \\
Dr11 & $y=7.621 e^{0.0604 x}$ & $R^{2}=0.7886$ & $y=8.0752 e^{0.0458 x}$ & $R^{2}=0.9347$ \\
Dr14 & $y=5.2505 e^{0.0676 x}$ & $R^{2}=0.7903$ & $y=3.7532 e^{0.1528 x}$ & $R^{2}=0.7738$ \\
S1 & $y=4.5725 e^{0.0717 x}$ & $R^{2}=0.9591$ & $y=1.153 e^{0.3069 x}$ & $R^{2}=0.8695$ \\
S2 & $y=3.2991 e^{0.0977 x}$ & $R^{2}=0.9339$ & $y=1.1018 e^{0.2501 x}$ & $R^{2}=0.9066$ \\
S3 & $y=2.7596 e^{0.1016 x}$ & $R^{2}=0.9254$ & $y=0.7688 e^{0.2367 x}$ & $R^{2}=0.9544$ \\
S4 & $y=3.6258 e^{0.1079 x}$ & $R^{2}=0.6979$ & $y=0.7328 e^{0.172 x}$ & $R^{2}=0.9362$ \\
S5 & $y=4.8046 e^{0.0834 x}$ & $R^{2}=0.958$ & $y=1.5462 e^{0.1135 x}$ & $R^{2}=0.7652$ \\
S6 & $y=5.5536 e^{0.0552 x}$ & $R^{2}=0.8698$ & $y=2.0479 e^{0.1038 x}$ & $R^{2}=0.8484$ \\
S7 & $y=5.7606 e^{0.0459 x}$ & $R^{2}=0.884$ & $y=4.5789 e^{0.0745 x}$ & $R^{2}=0.9553$ \\
S8 & $y=5.7004 e^{0.1168 x}$ & $R^{2}=0.9397$ & $y=5.2388 e^{0.0759 x}$ & $R^{2}=0.9477$ \\
S9 & $y=8.0663 e^{0.0787 x}$ & $R^{2}=0.9797$ & $y=3.9538 e^{0.0955 x}$ & $R^{2}=0.886$ \\
S10 & $y=7.7298 e^{0.0796 x}$ & $R^{2}=0.9237$ & $R^{2}=0.9566$ \\
\hline
\end{tabular}

of $\mathrm{C}_{\min }$ up to $\mathrm{C}_{\max } / \mathrm{MIC}$ ], in time $(\mathrm{t})$, where: $\mathrm{N}=$ variations in concentrations of Salmonella population dynamic $=\left(\mathrm{N}_{0}-\mathrm{N}_{\mathrm{t}}\right), \mathrm{t}=$ variations time $\left(\mathrm{t}_{0}-\mathrm{t}_{1}\right)$. The MIC and the $(\alpha)$ target values for these indices are 16 and 32 , respectively and become $\left(C_{16}, C_{32}\right)$. The $(\alpha)$ elimination of the initial concentration of antibiotics affected bacteria [resistant - mortality $(\mathrm{s}-\mathrm{m})$ ] and $\mathrm{E}=$ prediction of multidrug Salmonella resistance outbreak where $(\mathrm{N}, \mathrm{t} \neq 0)$.

Changes in these populations depend only on the net growth rate at time $(\mathrm{t})$. Where $\mathrm{a}, \mathrm{b}$ are positive constants and the initial bacteria $\mathrm{N}$ at time $(0)=\mathrm{N}_{0}$, If $\mathrm{a}>\mathrm{b}$ the bacteria grow exponentially, if $\mathrm{a}<\mathrm{b}$ the bacteria die out as shown in (Table 5)

It was assumed that resistant bacteria occurred with a constant rate during the whole experimental period. Since different sub-populations resemble patterns of infection-causing inoculums (one highly susceptible with $\mathrm{MIC}=2.0 \mu \mathrm{g} / \mathrm{mL}$, and one more resistant with an $\mathrm{MIC}=5.0 \mu \mathrm{g} / \mathrm{mL}$ ) that differ not only in $\mathrm{EC}_{\max 50}$ but also in the slope of their relationship to drug concentrations which is simulated as the outcome of treatment regimen illustrated in (Fig. 5).

\section{Discussion}

The increasing of multi drugs resistant bacteria in Sudan is a real issue and a major concern for all health authorities [31]. Although massive reports mentioned the increasing of resistance globally but the current patterns of MDR Salmonella spp. in Sudan is acceptable [32]. For effective measuring patterns and predicting of bacteria resistance, a microbial monitoring system was launched for Soba and Omdurman Military Hospital Stabilisation Stations were Salmonella Typhi originated from infected humans and survive during treatment at stations' ponds to invade the environment [33-35] have previously reported this epidemiological issue. The system was effectual for collections of samples especially during rainy seasons when outbreaks were expected; these agreed with [36] who also highlighted the hazard

Table 5 Outbreaks' simulation system parameters

\begin{tabular}{|c|c|c|c|c|}
\hline Description & Parameter & Estimated value & Simulated value & Units \\
\hline Initial population & $\mathrm{N}_{0}$ & $y=n e^{x}$ & 1.0000 & Cell/mL \\
\hline Bacteria replication time & t & $(t>0)$ & 30 & $\min$ \\
\hline Bacterial replication rate & r & $\ln x^{(+a)}$ & 100 & \\
\hline Mortality of bacteria & $\mathrm{m}$ & $\ln x^{(-b)}$ & 25 & \\
\hline Probability to resist antibiotics & $\Delta$ & & 2.00 & \\
\hline Antibiotics influence dose & a & $C_{16}, C_{32}$ & 2.0 and 5.0 & $\mu \mathrm{g} / \mathrm{mL}$ \\
\hline Final population & $\mathrm{N}_{\mathrm{t}}$ & $\ln x^{(a-b)}$ & 2.99573 & Cell/mL \\
\hline Resisted individuals (survived) & $\mathrm{N}$ & $\ln (x)$ & 12 & \\
\hline Prediction of outbreaks & $E$ & & $-13.00 \%$ & \\
\hline
\end{tabular}


of scattering resistant Salmonella strains from wastewater to the environment and infect humans again. Fourth generation Fluoroquinolone antibiotics are commonly used in Sudan to treat a variety of illnesses such as respiratory and urinary tract infections [37-39]. These antibiotics were tested and the proposed breakpoints were calculated with a standard E. coli ATCC 25922 reference as the Clinical and Laboratory Standards Institute (CLSI) recommendation for quality control, this in agreement with [28, 40, 41]. Interpretation of antibiotics' susceptibility for Salmonella Typhi include ciprofloxacin, gemifloxacin, levofloxacin, moxifloxacin, norfloxacin, and ofloxacin showed sensitive pattern of cotrimoxazole, gentamycin and ciprofloxacin to all isolated strain (Fig. 1) and resistance to some of the others, this agreed [42-44] who reported similar results of Ciprofloxacin susceptibility pattern for Salmonella Paratyphi indicating their sensitivity as antimicrobial. Statistical explanation of antibiogram indicated regular pattern of susceptibility by determining MICs and MBCs breakpoints of the isolated strains at $(16 \mu \mathrm{g} / \mathrm{mL})$ as threshold, the result agreed [45] and explained by [46, 47], when the isolated strain become more tolerant to the antibiotics they showed higher MICs without new mutation after $8 \mu \mathrm{g} / \mathrm{mL}$. Moreover, probability trends in the MIC or its resultant MBC distribution above the threshold may not be observed whereas the distribution to the left of the threshold is not expected to change over time [48]. When such changes in the resistant isolated strain are expected then the ordinal or quantitative scale of distribution trends needs to be considered as confirmed by [49]. The probability of Salmonella Typhi resistance may occur during the course, and it can be plotted as linear equation (Eq. 1), where the coefficient of isolated strain found to be resistant as calculated in (Fig. 2), [50] reported the application of related antibiotics such as (beta-lactam antibiotics and macrolides) and the log odds of resistance could be modelled in the course of linear regression where a strong linear and statistically significant relationship is confirmed. The in vitro prediction of resistance trends demonstrated that the scale of the impact was relatively more influential for cotrimoxazole, gentamycin and ciprofloxacin, (Tables 2 and 3), [51] identifying the MIC of antimicrobial agent is an effective assessment for clinical success using breakpoints determination for predicting and detecting the probability of resistant populations during specific timeline. The emergence of resistance pattern could be predicted by changing the values from actual to forecast in the time-line of the experiment (Figs. 3 and 4) depending on bacteria exponential growth during antibiotics course (Eq. 2), reports from [52-54] confirmed that; various antimicrobial agents are related to the emergence of resistance during prolonged therapy. Consequently, isolated strains that are originally susceptible may become resistant within three to 4 days after the beginning of treatment [55]. Conversely, the previous records of rapid emergence of resistance to recently introduced antibiotics indicates that even new families of antibiotics will

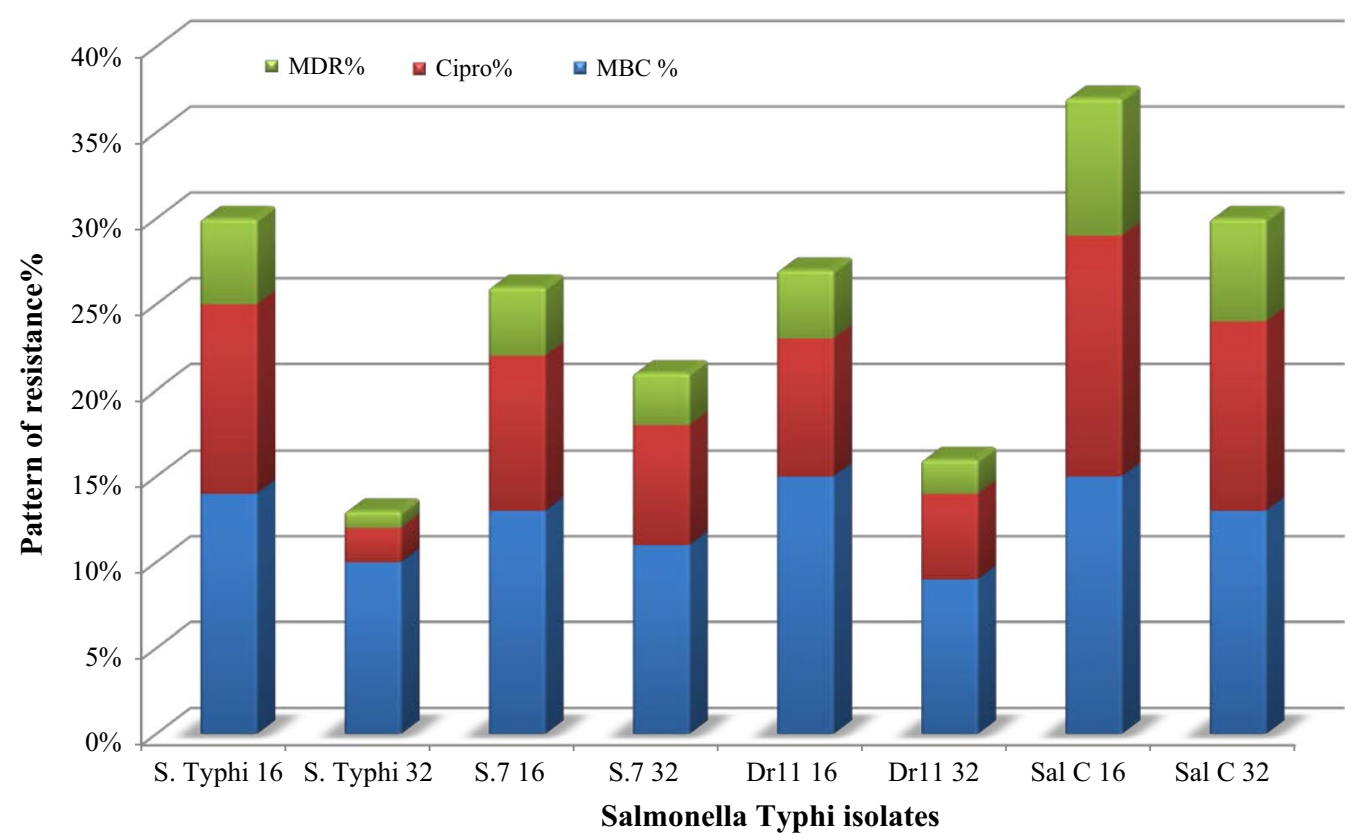

Fig. 1 Antibiogram criteria for multi-drug resistant strains 


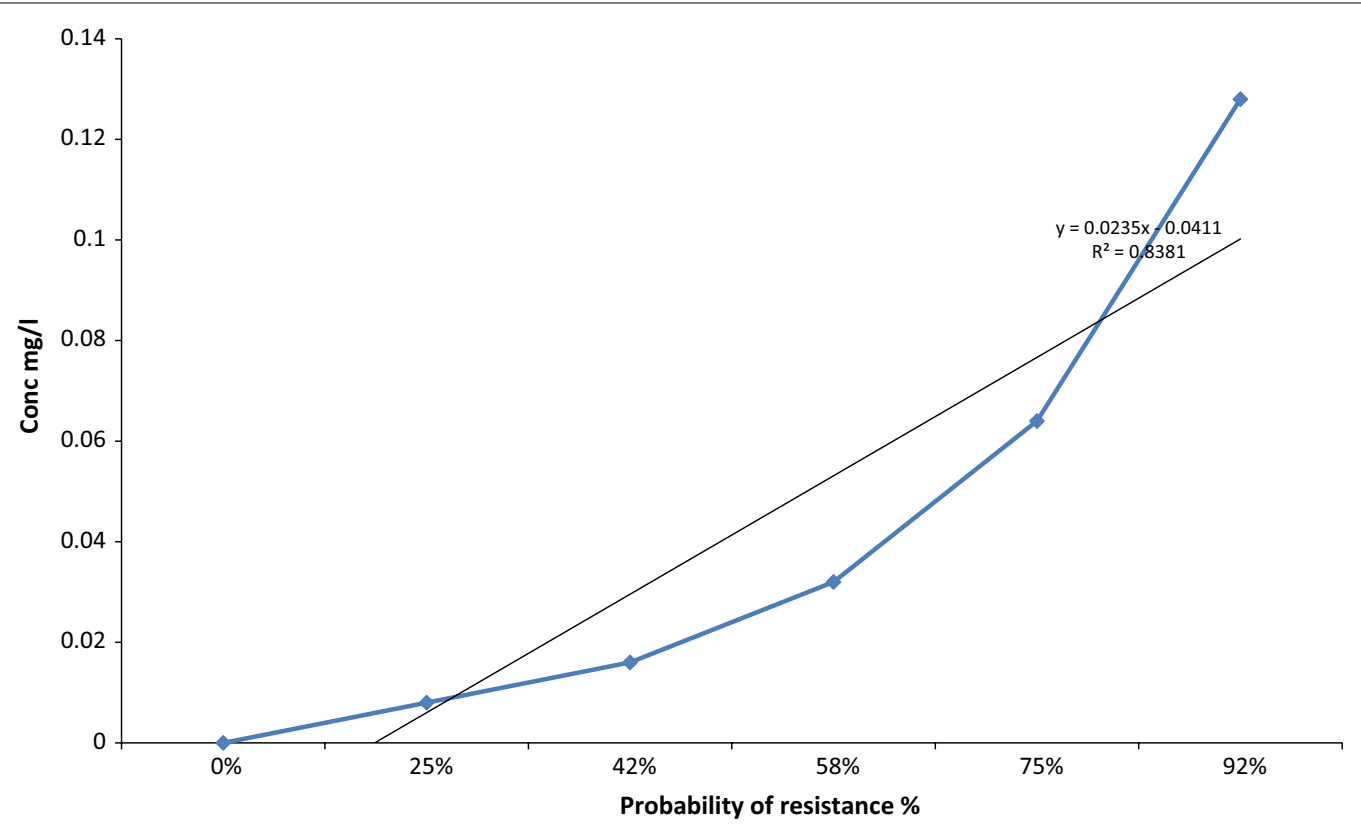

Fig. 2 Antibiotics normal probability plot

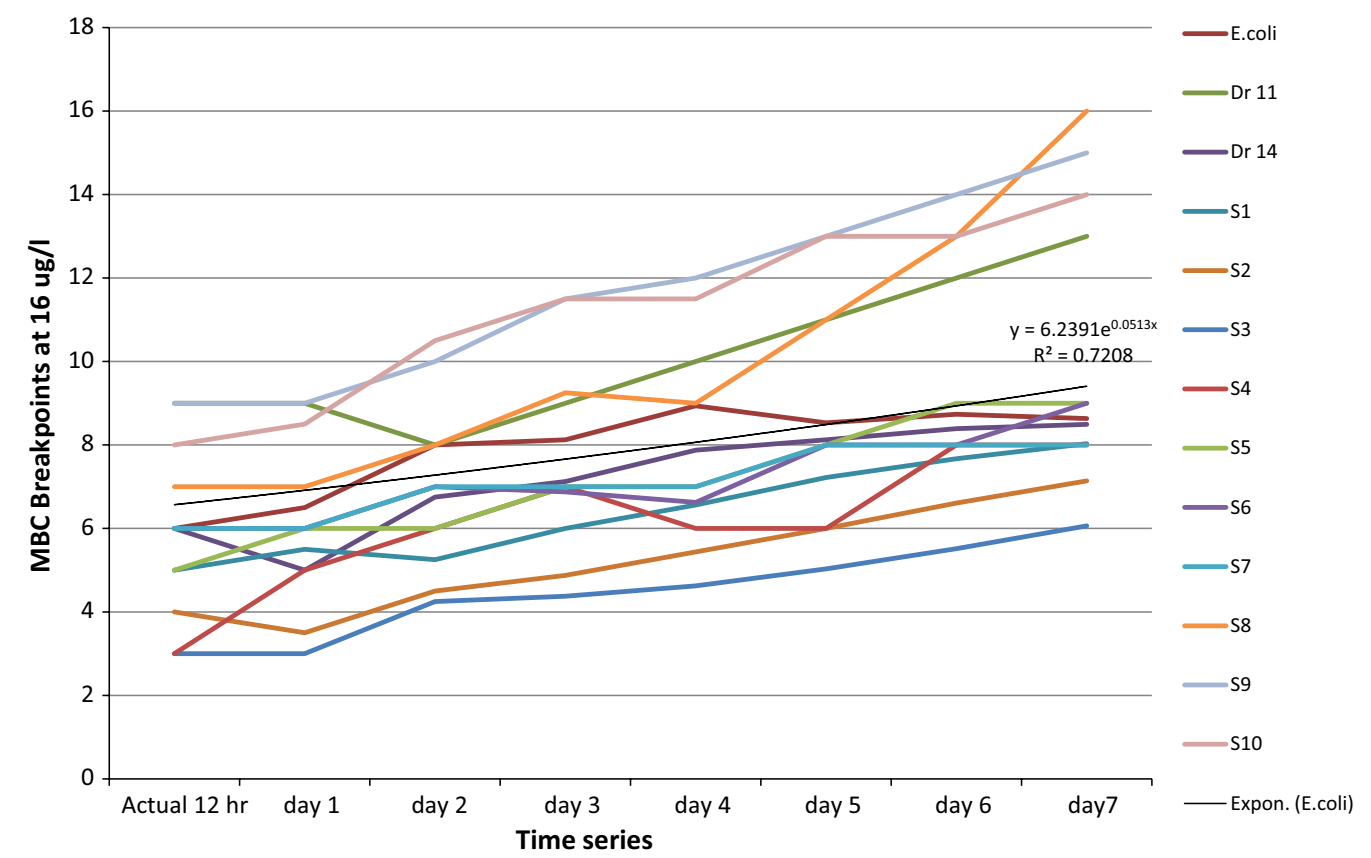

Fig. 3 Prediction of antibiotics MBC resistance's trends at $16 \mu \mathrm{g} / \mathrm{mL}$

have a short life expectancy [56], to avoid this critical issue, a predictive system was created and applied during collection of samples. Earlier information of antibiotic's efficiency in treating a bacterial infection can potentially play a major role in controlling serious outbreaks [57, 58], the long-term prediction of bacterial population and antibiotics dynamics was modelled (Eqs. 3 and 4) using such information. Therefore, the purpose of in silico simulation models as shown in (Table 4) for this research is to observe the seasonal typhoid incidents computationally because it is essential to predict the outcome of their trended outbreaks as reported by [59]. To control a 

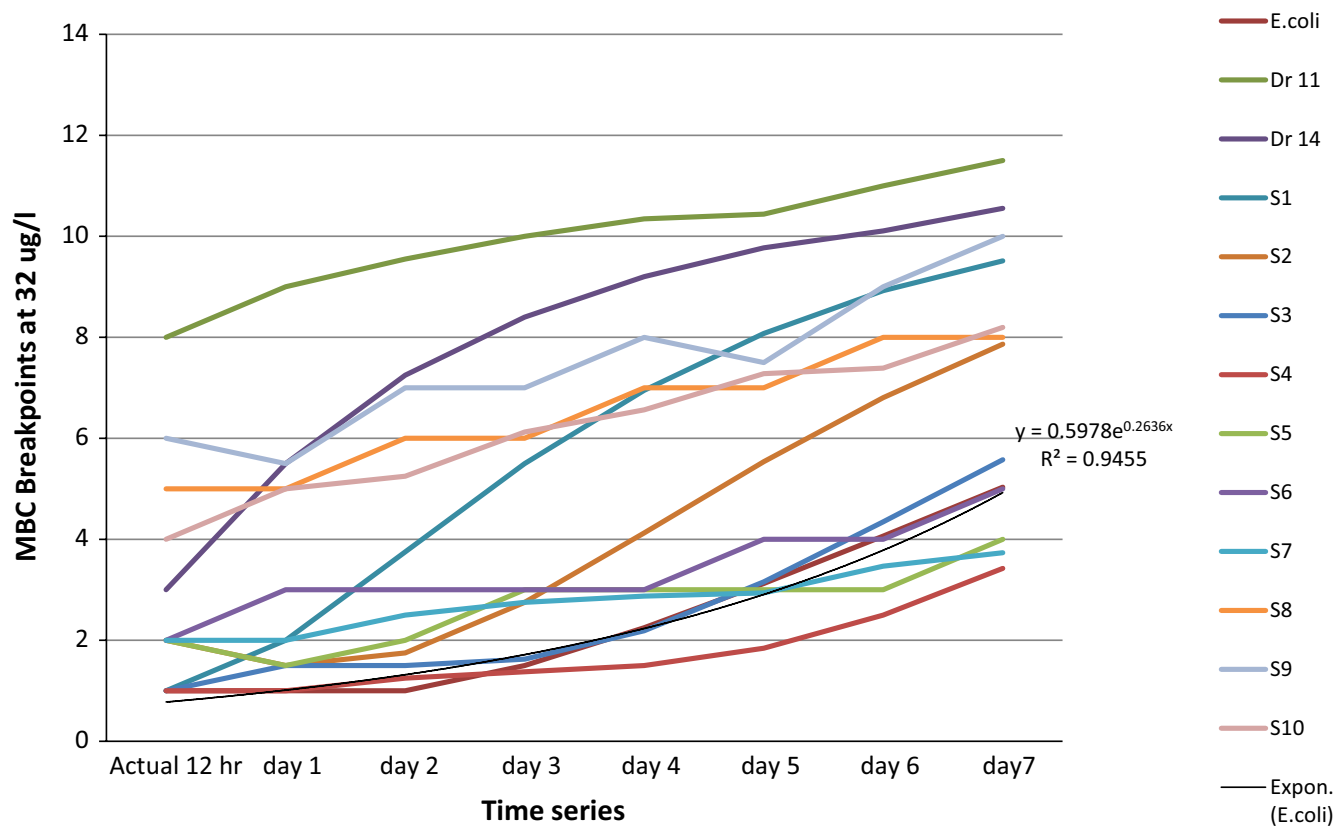

Fig. 4 Linear predicition of antibiotics MBC resistance's trends at $32 \mu \mathrm{g} / \mathrm{mL}$
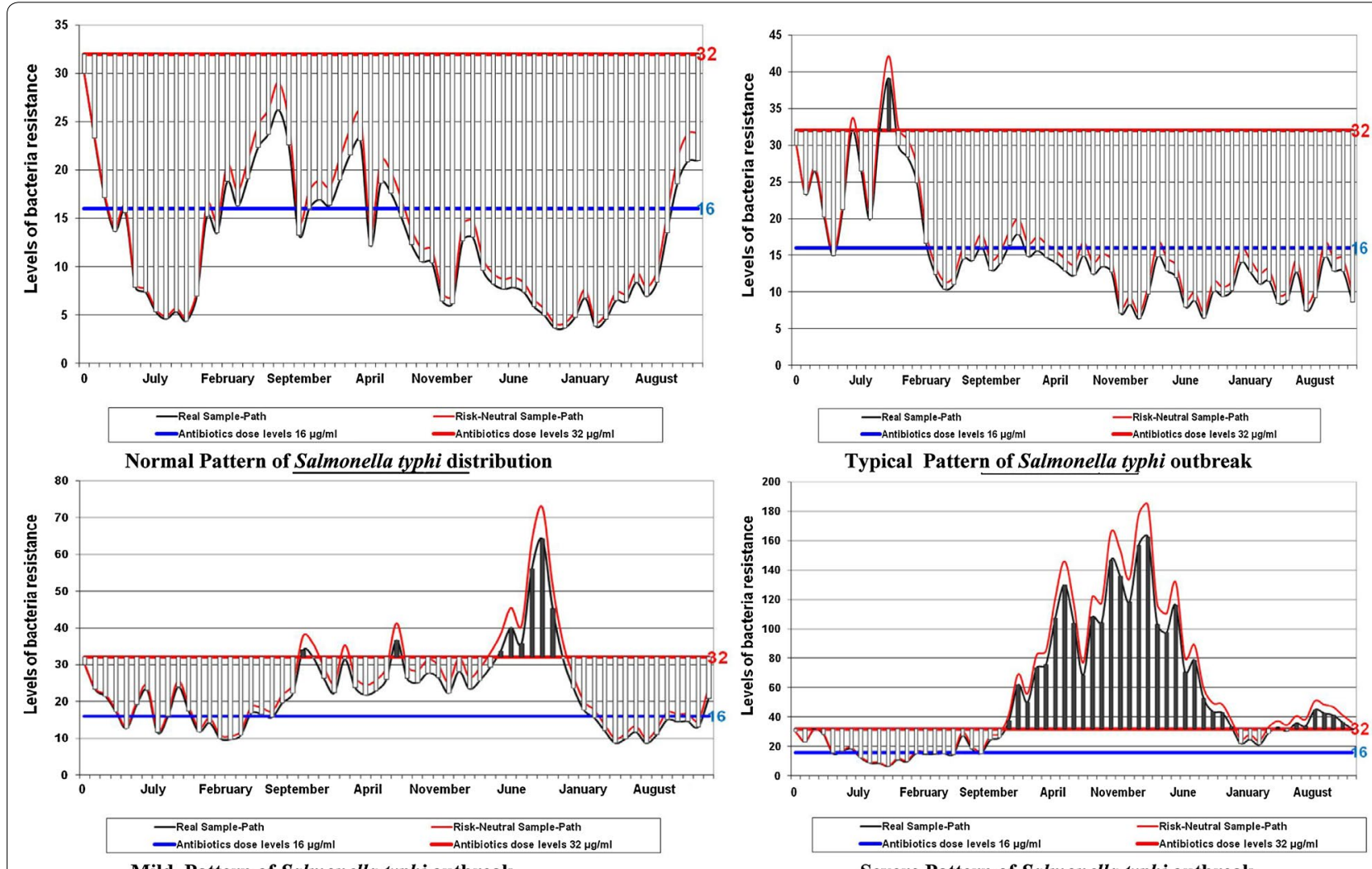

Mild Pattern of Salmonella typhi outbreak

Severe Pattern of Salmonella typhi outbreak

Fig. 5 In silico simulations of MDR Salmonella Typhi outbreaks. The in silico monitoring system is a computational program based on Microsoft Excel sheet describes the predicting statistics was found to be suitable for monitoring the seasonal typhoid incidents during the outbreaks 
successful strategy of a typical disease scenario (Fig. 5), the measure plan is to eliminate the causative bacteria before it has the opportunity to spread and infect more population. However, modelling is essential in drug development for certain pathogenic population, and it contains many complex processes that require robust of basic procedures for predicting clean data, fitting computing platforms, sufficient resources, and valuable communication. Absolutely, the application of model-based approaches for drug development and for maximizing the clinical potential of drugs is a complex and developing field, precisely in silico models that have considerable attention during outbreaks because they are essential for connecting pharmacokinetics information and clinical outcomes [60].

\section{Conclusion}

The present patterns of ciprofloxacin susceptibility are in normal ranges. This study assesses the prediction of multi-drug resistance among $S$. Typhi isolates by applying low cost materials and simple statistical methods suitable for the most frequently used antibiotics as experimental therapy. Consequently, bacterial surveillance systems were implemented to present data on the aetiology and current antimicrobial drug resistance patterns of community-acquired agents causing bacteraemia and outbreaks.

\section{Additional file}

Additional file 1. Prediction of MDR Salmonella Typhi Simulations.

\begin{abstract}
Authors' contributions
AAE, Ph.D. student: has conducted the research for the degree requirements, he collected data, laboratory investigations, statistical analysis wrote the manuscript and corresponding author. Dr. AAA, Co-supervisor: biochemical analysis, manuscript review and correction. Dr. MAES, Co-supervisor: molecular biology analysis, manuscript review and correction. Prof. AAEH, Supervisor: microbial analysis, manuscript detailed review, correction and final approval. All authors read and approved the final manuscript.

\footnotetext{
Author details

${ }^{1}$ Faculty of Science, University of Khartoum, Khartoum, Sudan. ${ }^{2}$ Albaha University, Al Bahah, Saudi Arabia.
}

\section{Competing interests}

The authors declare that they have no competing interests.

\section{Consent for publication}

I Ayman Elshayeb, give my consent for information about myself/my child or ward/my relative (circle as appropriate) to be published in Availability of data and material. I understand that the information will be published without my/ my child or ward's/my relative's (circle as appropriate) name attached, but that full anonymity cannot be guaranteed. I understand that the text and any pictures or videos published in the article will be freely available on the internet and may be seen by the general public. The pictures, videos and text may also appear on other websites or in print, may be translated into other languages or used for commercial purposes I have been offered the opportunity to read the manuscript.
Ethics approval and consent to participate

This research is not involving human subjects, human material, or human data, according to the Declaration of Helsinki it did not need to be approved by an appropriate ethics committee.

\section{Funding}

This research has not received any fund from international or national body, al the materials and equipment were facilitated by the microbiology laboratory of the University of Khartoum and Karary University.

\section{Publisher's Note}

Springer Nature remains neutral with regard to jurisdictional claims in published maps and institutional affiliations.

Received: 17 May 2017 Accepted: 4 November 2017

Published online: 14 November 2017

References

1. Singh A, Verma HN, Arora K. Surface plasmon resonance based label-free detection of Salmonella using DNA self assembly. Appl Biochem Biotechnol. 2015;175:1330-43.

2. Crump JA, Luby SP, Mintz ED. The global burden of typhoid fever. Bull World Health Organ. 2004;82:346-53.

3. Alirol E, Horie NS, Barbe B, Lejon V, Verdonck K, Gillet P, Jacobs J, Buscher P, Kanal B, Bhattarai NR, et al. Diagnosis of persistent fever in the tropics: set of standard operating procedures used in the NIDIAG febrile syndrome study. PLoS Negl Trop Dis. 2016;10:e0004749.

4. Hyams KC, Oldfield EC, Scott RM, Bourgeois AL, Gardiner H, Pazzaglia G, Moussa M, Saleh AS, Dawi OE, Daniell FD. Evaluation of febrile patients in Port Sudan, Sudan: isolation of dengue virus. Am J Trop Med Hyg. 1986:35:860-5

5. Mukhtar ED, Mekki MO. Trimethoprim-sulphamethoxazole in the treatment of enteric fever in the Sudan. Trans R Soc Trop Med Hyg. 1981;75:771-3

6. Maurya P, Gulati AK, Nath G. Status of Vi gene, its expression and Salmonella pathogenicity island (SPI-7) in Salmonella typhi in India. Southeast Asian J Trop Med Public Health. 2010;41:913-9.

7. Ramos JM, Vidal I, Bellot P, Gomez-Hurtado I, Zapater P, Such J. Comparison of the in vitro susceptibility of rifaximin versus norfloxacin against multidrug resistant bacteria in a hospital setting. A proof-of-concept study for use in advanced cirrhosis. Gut. 2016;65:182-3.

8. Bellot $\mathrm{P}$, Jara PL, Martinez MB, Such J, Current problems in the prevention and treatment of infections in patients with cirrhosis. Gastroenterol Hepatol. 2010;33:729-40.

9. Singhal L, Gupta PK, Kale P, Gautam V, Ray P. Trends in antimicrobial susceptibility of Salmonella Typhi from North India (2001-2012). Indian J Med Microbiol. 2014;32:149-52.

10. Duran GM. Antibiotic-resistant bacteria in ready-to-eat shrimp. MS: Mississippi State University; 2003

11. Yan H, Tian M, Row KH. Determination of enrofloxacin and ciprofloxacin in milk using molecularly imprinted solid-phase extraction. J Sep Sci. 2008;31:3015-20.

12. Shrestha KL, Pant ND, Bhandari R, Khatri S, Shrestha B, Lekhak B. Reemergence of the susceptibility of the Salmonella spp. isolated from blood samples to conventional first line antibiotics. Antimicrob Resist Infect Control. 2016;5:22.

13. Veeraraghavan B, Anandan S, Sethuvel DPM, Puratchiveeran N, Walia K, Ragupathi NKD. Molecular characterization of intermediate susceptible typhoidal Salmonella to ciprofloxacin, and its impact. Mol Diagn Ther. 2016:20:213-9.

14. Wasihun AG, Wlekidan LN, Gebremariam SA, Dejene TA, Welderufael AL, Haile TD, Muthupandian S. Bacteriological profile and antimicrobial susceptibility patterns of blood culture isolates among febrile patients in Mekelle Hospital, Northern Ethiopia. Springerplus. 2015;4:314.

15. Renukananda GS, Santhosh UP, George NM. Topical vs combination ciprofloxacin in the management of discharging chronic suppurative otitis media. J Clin Diagn Res. 2014;8:KC01-4. 
16. Collee JG, Mackie TJ. Mackie and McCartney practical medical microbiology. 14th ed. Edinburgh: Churchill Livingstone; 1996.

17. Kinney EL. Isolation identification and antimicrobial susceptibility analysis of Enterococccus spp. and Salmonella spp. from conventional poultry farms transitioning to organic farming practices. College Park: University of Maryland, College Park; 2009.

18. Tatham LM. Analysis of the inhibitory activity and mode of action of novel antimicrobial organic nanoparticles. Thesis (Ph.D.). University of Liverpool; 2011.

19. Findlay J, Amyes S, Hamouda A. Klebsiella pneumoniae: a progression to multidrug resistance. Thesis (Ph.D.). University of Edinburgh; 2012.

20. Davies SE, Amyes SGB. Development of antimicrobial resistance in Acinetobacter spp and methicillin-resistant Staphylococcus aureus. Thesis (Ph.D.). University of Edinburgh; 2009.

21. Ou B. Photooxidation mechanism for ciprofloxacin, fleroxacin and lomefloxacin. Thesis (Ph.D.). Massachusetts College of Pharmacy and Health Sciences; 2000 .

22. Li Y, Knovel (Firm): Materials for modern technologies selected, peer reviewed papers from the 2015 Spring International Conference on material sciences and technology (MST-S), April 14-16, 2015, Beijing, China. In: Advanced materials research, vol. 1104. p. 1 online resource (168 pages) illustrations (some color). Zurich: Trans Tech Publishers; 2015:1 online resource (168 pages) illustrations (some color).

23. Langel Ü (editor). Cell-penetrating peptides methods and protocols. In: Methods in molecular biology, vol. 683. p. 1 online resource (Xv, p. 586) New York: Humana; 2011:1 online resource (xv, p. 586).

24. Mattick KL, Legan JD, Humphrey TJ, Peleg M. Calculating Salmonella inactivation in nonisothermal heat treatments from isothermal nonlinear survival curves. J Food Prot. 2001:64:606-13.

25. Pitzer VE, Feasey NA, Msefula C, Mallewa J, Kennedy N, Dube Q, Denis B, Gordon MA, Heyderman RS. Mathematical modeling to assess the drivers of the recent emergence of typhoid fever in Blantyre, Malawi. Clin Infect Dis. 2015;61(Suppl 4):S251-8.

26. International Organization for Standardization. Microbiology of food and animal feeding stuffs-horizontal method for the detection of Salmonella spp. $=$ Microbiologie des aliements - méthode horizontale pour la recherche des Salmonella spp. 4th ed. Geneva: International Organization for Standardization; 2002

27. Jorgensen JH. Methods for antimicrobial dilution and disk susceptibility testing of infrequently isolated or fastidious bacteria: approved guideline. Wayne: Clinical and Laboratory Standards Institute; 2006.

28. Darwish AM, Farmer BD, Hawke JP. Improved method for determining antibiotic susceptibility of Flavobacterium columnare isolates by broth microdilution. J Aquat Anim Health. 2008;20:185-91.

29. Agrawal GN, Shevade SU. Comparison of clinical and laboratory standards institute 2008 and 2010 guidelines in interpreting susceptibility of enterobacteriaceae isolates. Indian J Pathol Microbiol. 2014;57:518-9.

30. Elshayeb A, Ayman AAA, El Siddig MA, El Hussien AAA. In silico simulation of lytic bacteriophage population dynamics and its bacterial host Salmonella typhi. EC Microbiology. 2016:3:10.

31. Ibrahim ME, Bilal NE, Hamid ME. Comparison of phenotypic characteristics and antimicrobial resistance patterns of clinical Escherichia coli collected from two unrelated geographical areas. Glob J Health Sci. 2014;6:126-35.

32. Elmadiena MM, El Hussein AA, Muckle CA, Cole L, Wilkie E, Mistry K, Perets A. Antimicrobial susceptibility and multi-drug resistance of Salmonella enterica subspecies enterica serovars in Sudan. Trop Anim Health Prod. 2013:45:1113-8.

33. Medeiros JD, Araujo LX, da Silva VL, Diniz CG, Cesar DE, Del'Duca A, Coelho CM. Characterization of the microbial community in a lotic environment to assess the effect of pollution on nitrifying and potentially pathogenic bacteria. Braz J Biol. 2014;74:612-22.

34. Baig SA, Xu X, Khan R. Microbial water quality risks to public health: potable water assessment for a flood-affected town in northern Pakistan. Rural Remote Health. 2012;12:2196.

35. Yajima A, Koottatep T. Assessment of E. coli and Salmonella spp. infection risks associated with different fecal sludge disposal practices in Thailand. J Water Health. 2010;8:355-64.

36. Masarikova M, Manga I, Cizek A, Dolejska M, Oravcova V, Myskova P, Karpiskova R, Literak I. Salmonella enterica resistant to antimicrobials in wastewater effluents and black-headed gulls in the Czech Republic, 2012. Sci Total Environ. 2016:542:102-7.
37. Dsugi NF, Elbashir AA, Suliman FE. Supramolecular interaction of gemifloxacin and hydroxyl propyl beta-cyclodextrin spectroscopic characterization, molecular modeling and analytical application. Spectrochim Acta A Mol Biomol Spectrosc. 2015;151:360-7.

38. Dsugi NF, Elbashir AA. Supramolecular interaction of Moxifloxacin and beta-cyclodextrin spectroscopic characterization and analytical application. Spectrochim Acta A Mol Biomol Spectrosc. 2015;137:804-9.

39. Ahmed AA, Osman H, Mansour AM, Musa HA, Ahmed AB, Karrar Z, Hassan HS. Antimicrobial agent resistance in bacterial isolates from patients with diarrhea and urinary tract infection in the Sudan. Am J Trop Med Hyg. 2000;63:259-63.

40. JiWJ, Xu XW, Dong F. Detection and drug resistance analysis of extendedspectrum beta-lactamases-producing Shigella in pediatric patients. Zhonghua Er Ke Za Zhi. 2010;48:617-20.

41. Shen JL, Yang BW, Zhi S, Cui SH, Xi ML, Yang PF, Meng JH. Detection and analysis of antibiotic resistance of Salmonella from retail meats in some districts of Shaanxi province. Zhonghua Yu Fang Yi Xue Za Zhi. 2008:42:758-61.

42. Choudhary A, Gopalakrishnan R, Nambi PS, Ramasubramanian V, Ghafur KA, Thirunarayan MA. Antimicrobial susceptibility of Salmonella enterica serovars in a tertiary care hospital in southern India. Indian J Med Res. 2013;137:800-2.

43. Bhattacharya SS, Das U, Choudhury BK. Occurrence \& antibiogram of Salmonella typhi \& S. paratyphi A isolated from Rourkela, Orissa. Indian J Med Res. 2011;133:431-3.

44. Rollo MA, Buccoliero G, Lonero G, Romanelli C, Loperfido P, Cristiano L, Chimienti A, Angelini P, Resta F. No fluoroquinolone resistance in non typhoidal salmonellas from hospitalized persons in an endemic area of Apulia, Italy. Recenti Prog Med. 2004;95:414-7.

45. Sheppard SK, Lloyd D. Effects of soil amendment on gas depth profiles in soil monoliths using direct mass spectrometric measurement. Bioresour Technol. 2002;84:39-47.

46. Meumann EM, Mitchell BG, McGregor A, McBryde E, Cooley L. Urinary Escherichia coli antimicrobial susceptibility profiles and their relationship with community antibiotic use in Tasmania, Australia. Int J Antimicrob Agents. 2015;46:389-93.

47. Filip R, Poiata A, Coman G, Dahorea C, Tuchilus C. Resistance mechanism for a number of non-typhoidic Salmonella strains isolated in lasi, Romania. Rev Med Chir Soc Med Nat lasi. 2000;104:109-12.

48. Glupczynski Y, Delmee M, Goossens H, Struelens M. Belgian multicenter ICUSG: distribution and prevalence of antimicrobial resistance among gram-negative isolates in intensive care units (ICU) in Belgian hospitals between 1996 and 1999. Acta Clin Belg. 2001;56:297-306.

49. Lo JZ, Leow JJ, Ng PL, Lee HQ, Mohd Noor NA, Low JK, Junnarkar SP, Woon WW. Predictors of therapy failure in a series of 741 adult pyogenic liver abscesses. J Hepato-biliary Pancreat Sci. 2015;22:156-65.

50. Farmakiotis D, Varughese J, Sue P, Andrews P, Brimmage M, Dobroszycki J, Coyle CM. Typhoid fever in an inner city hospital: a 5-year retrospective review. J Travel Med. 2013;20:17-21.

51. Bresler SC, Weiser DA, Huwe PJ, Park JH, Krytska K, Ryles H, Laudenslager M, Rappaport EF, Wood AC, McGrady PW, et al. ALK mutations confer differential oncogenic activation and sensitivity to ALK inhibition therapy in neuroblastoma. Cancer Cell. 2014;26:682-94.

52. Xu L, Wang H, Yang X, Lu L. Integrated pharmacokinetics/pharmacodynamics parameters-based dosing guidelines of enrofloxacin in grass carp Ctenopharyngodon idella to minimize selection of drug resistance. BMC Vet Res. 2013:9:126.

53. Ding F, Zarlenga DS, Ren Y, Li G, Luan J, Ren X. Use of the D-R model to define trends in the emergence of Ceftazidime-resistant Escherichia coli in China. PLoS ONE. 2011;6:e27295.

54. Turnidge J. Pharmacokinetics and pharmacodynamics of fluoroquinolones. Drugs. 1999;58(Suppl 2):29-36.

55. Feasey NA, Gaskell K, Wong V, Msefula C, Selemani G, Kumwenda S, Allain TJ, Mallewa J, Kennedy N, Bennett A, et al. Rapid emergence of multidrug resistant, H58-lineage Salmonella typhi in Blantyre, Malawi. PLoS Negl Trop Dis. 2015:9:e0003748.

56. Keeney KM, Yurist-Doutsch S, Arrieta MC, Finlay BB. Effects of antibiotics on human microbiota and subsequent disease. Annu Rev Microbiol. 2014;68:217-35.

57. Lodes $\mathrm{U}$, Lippert H, Meyer F. Molecular biological sepsis diagnostic using multiplex PCR in surgical intensive care as suitable alternative to conventional microbial culture - a representative overview. Zentralbl Chir. 2011;136:135-42. 
58. Waggoner DM. Enhancing the cost-effective practice of medicine: the physician's perspective. Top Health Inf Manag. 1993;14:22-31.

59. Knipl D. A new approach for designing disease intervention strategies in metapopulation models. J Biol Dyn. 2016;10:71-94.
60. van Kleef E, Robotham JV, Jit M, Deeny SR, Edmunds WJ. Modelling the transmission of healthcare associated infections: a systematic review. BMC Infect Dis. 2013;13:294.

\section{Submit your next manuscript to BioMed Central} and we will help you at every step:

- We accept pre-submission inquiries

- Our selector tool helps you to find the most relevant journal

- We provide round the clock customer support

- Convenient online submission

- Thorough peer review

- Inclusion in PubMed and all major indexing services

- Maximum visibility for your research

Submit your manuscript at www.biomedcentral.com/submit 